\title{
Szesnastowieczne pobizantyńskie freski z Supraśla w świetle dokumentacji konserwatorskiej - historia zniszczeń
}

\author{
Krystyna Stawecka \\ Muzeum Ikon w Supraślu \\ Oddział Muzeum Podlaskiego w Białymstoku \\ k.stawecka@muzeum.bialystok.pl
}

\begin{abstract}
Krystyna Stawecka, 16th-century Byzantine Frescoes from Supraśl In the Light of Conservation Documentation - the History of Destruction, Elpis, 19 2017: 139-147.

Abstract: The article is dedicated to the history of the unique 16th-century Byzantine frescoes in Suprasl. Here we find an attempt of determining an exact date of accomplishment of the interior wall ornamentation (as well as establishing its authorship) in the Orthodox Church of the Annunciation of the Mother of God in Suprasl. The main part of the text contains a description of the successive stages of polychromy degradation that started with the damages caused by new elements of the interior decoration added in the seventeenth century (iconostasis, side altars) and was continued in the 18th century when the large parts of the frescoes were panelled. Later on the profound alteration of the architectural and painting of the presbytery was made. It ended with almost complete destruction of the frescoes during the World War II. The part of the text also mentions the restorative treatments conducted on this monument since the end of the 19th century. Here we can also find the study of preserving the extant fragments of the paintings during the post-war times. The analysis of the conservatory measures and their documentation taken between 1964-1965 (66) as well as in 2012 and 2014 closes the article.
\end{abstract}

\begin{abstract}
Streszczenie: Artykuł poświęcony jest historii unikatowych, szesnastowiecznych pobizantyńskich fresków supraskich. Znajdziemy w nim próbę określenia czasu powstania dekoracji malarskiej cerkwi Zwiastowania Bogarodzicy w Supraślu, głównej świątyni zgromadzenia monastycznego, a także jej autorów. Zasadnicza część tekstu zawiera opisy kolejnych etapów degradacji polichromii, poczynając od uszkadzających ją nowych elementów wyposażenia wnętrza, pojawiających się w siedemnastym wieku (ikonostas, ołtarze boczne), poprzez zakrycie malowideł w XVIII w. tabulaturą i całkowitą zmianę wystroju architektoniczno-malarskiego prezbiterium, skończywszy na niemal doszczętnym zniszczeniu fresków w czasie II wojny światowej. W części tej znalazły się również odniesienia do zabiegów restauratorskich prowadzonych nad tym zabytkiem od końca XIX w. Omówienie działań ratujących ocalałe fragmenty malowideł, prowadzonych w powojennej rzeczywistości oraz dokumentacja prac konserwatorskich jakie miały miejsce w latach 1964-1965(66), jak również w 2012 i 2014 r., zamyka to opracowanie.
\end{abstract}

Keywords: frescoes, Supraśl, orthodox church, restoration

Slowa kluczowe: freski, Supraśl, cerkiew, konserwacja

Przyjmuje się, iż dekoracja malarska cerkwi Zwiastowania powstała w okresie, w którym archimandrytą klasztoru był Sergiusz Kimbar (1532-1565), nazywany ,architektem" tego zgromadzenia. Ten przedział czasowy zawężany jest do 1557 r., kiedy powstał spis dokumentujący majątek monasteru i dokonania jego przełożonego, gdzie znalazły się odniesienia do domniemanego autora polichromii. Józef Jodkowski w swoim artkule: Cerkwie przygotowane do obrony na Litwie i Litewskiej Rusi (opublikowanym w większym wydawnictwie: Starożytności. Prace Komisji nad ochrona dawnych zabytków, Sankt Petersburg 1915, nr 5, s. 249-311)1, w dwóch różnych miejscach podaje daty powstania polichromii. Najpierw pisze że: „W 1557 roku została »wymalowana święta cerkiew i ołtarz«”, powołując

Tyt. oryg. И. Иодковский, Церкви приспособленныя къ обороне въ Литве и Литовской Руси [w:] Древности. Труды комиссии по сохранению древнихъ памятниковъ, остоящей при Императорскомъ Московскомъ Археологическомъ Обществе, т. VI, Москва 1915, s. 249-311. się przy tym na Letopis supraskiego klasztoru (Лътопись Супрасльскаго монастыря, „Археографический Сборник документовъ относящихся къ истории северо -западной Руси", т. IX, Вильна 1870, стр. 47-48)2. Następnie zaś podaje bardziej ogólną informację: „Malowidła ścienne datowane są na lata pięćdziesiąte szesnastego wieku, gdy archimandrytą był Sergiusz Kimbar”, w tym przypadku nie opierając się na żadnym źródle ${ }^{3}$. Przy ustalaniu

\footnotetext{
Tamże, s. 255. Zapewne za nim datę tę powtarza L. Lebiedzińska w swym opracowaniu: Freski z Supraśla. Katalog wystawy. Biatystok 1968, Kraków 1968. Datowanie to pojawia się również w innych pracach poświęconych freskom supraskim.

3 Tamże, s. 264. Niewątpliwie Jodkowski cytuje opinie P.P. Pokryszkina, który w swej pracy: Cerkiew Zwiastowania w supraskim monasterze, Sankt Petersburg 1911, s. 11 (tyt. oryg. П.П. Покрышкинъ, Благовэщенская церков въ Супрасльскомъ Монастырэ, Санкт-Петербург 1911 - wydawnictwo to stanowi przedruk artykułu po raz pierwszy zamieszczonego pod tym samym tytułem w opracowaniu: „Сборникъ археологическихъ статей, поднесенный Графу А.А. Бобринскому въ день 25-летия председательства его въ Императорской Археологической Ком-
} 
czasu powstania fresków supraskich warto wziąć pod uwagę wydarzenie również odnotowane przez wspomnianego badacza, a odnoszące się do budowy: „[...] refektarza, a przy nim cerkwi, kuchni, komory lub magazynu ze sklepieniem i tynkami [...]" co miało mieć miejsce w $1545 \mathrm{r}^{4}$ Jeśli uznamy, że w notatce tej mowa jest o tzw. ciepłej cer$\mathrm{kwi}^{5}$, do której wspomniany - w cytowanym przez Jodkowskiego „Rejestrze” Sergiusza Kimbara - malarz Serb Nektariusz, określany jako jeden $\mathrm{z}$ twórców dekoracji malarskiej w głównej świątyni Zwiastowania NMP, miał wykonać Deesis i dwie inne ikony, to wówczas czas powstania fresków możemy przesunąc na lata czterdzieste XVI w. ${ }^{6}$ Bowiem logicznym wydaje się, że w pierwszej kolejności przełożony monasteru zatroszczył się o wykończenie wnętrza głównej świątyni, po czym mógł przystąpić do dalszych inwestycji. Na lata czterdzieste XVI stulecia wskazuje również A. Siemaszko, poddając dokładnej analizie cykl malowideł przedstawiających sceny z życia Chrystusa i dowodząc możliwość ukrycia w ich kompozycji czasu powstania polichromii. Rozważania te pozwoliły badaczowi wysnuć hipotezę, iż freski supraskie powstały w sezonie $1542 / 1543^{7}$. Warto przy tym wziąć pod uwagę także wizytę Zygmunta Augusta w Supraślu, która miała miejsce w 1544 r. Jednym z głównych jej powodów mogła

миссии 1886-1911”, Санкт-Петербургъ 1911, s. 222-237), datuje powstanie polichromii supraskiej na lata pięćdziesiąte XVI w. Jednocześnie autor ten przy wszystkich fotografiach dokumentujących stan fresków podaje $1557 \mathrm{r}$. jako czas powstania malowideł.

4 Tamże, s. 255

Za tzw. „ciepłą cerkiew” uznać możemy, wspomniany wcześniej, dobudowany jeszcze za czasów archimandryty Kimbara do południowo -wschodniego narożnika świątyni gmach określany jako refektarz, przy którym wymienia się cerkiew, diakonikon, zakrystię. W późniejszej tradycji budynek ten nazywany był „,ciepłą cerkwią”. Jak pisze P.P. Pokryszkin (dz. cyt., s. 5): „W 1853 r. ihumen Wincenty Żurowski zburzył w niej wewnętrzną ścianę, znajdującą się od strony diakonikonu, rozdzielającą korytarzyk wiodący od ołtarza na dziedziniec klasztorny, „zdjął cały dach z tej dobudówki i zbudował tu ciepłą cerkiew pod wezwaniem św. Jana Teologa, którą w 1890 r. przeniesiono do nowego, nie najładniejszego budynku, dobudowanego do typowego osiemnastowiecznego korpusu unickiego, w którym mieszczą się przeorskie cele". Autor swe relacje oparł na pracy archimandryty Mikołaja Dałmatowa: Supraski monaster Zwiastowania. Historyczne i statystyczne opisanie, Sankt Petersburg 1892 (tyt. oryg. Н. Далматовъ, „Супрасльский Благовещенский монастьрь. Историко-статистическое описание”, Санкт-Петербург 1892), w części powielającej zapisy z Kroniki Ławry Supraskiej (Лłmonucb Супрасльскаго монастыря, „Археографический Сборник документовъ относящихся къ истории северо-западной Руси”, т. IX, Вильна 1870) napisanej w większej części przed 1779 r., przez Mikołaja Radkiewicza hieromnicha supraskiego klasztoru. Ciepłą cerkwią mogła być również nazywana w owym czasie, wcześniej wzniesiona, zapewne drewniana, świątynia poświęcona św. Janowi Ewangeliście - jak twierdził S. Stawicki (Malowidła ścienne z dawnej cerkwi Zwiastowania NMP w Supraślu - problemy techniczne i technologiczne, „Biuletyn Konserwatorski Województwa Podlaskiego", 2004, z. 10, s. 10). Analiza źródeł dostarcza nam informacji o nowych inwestycjach czynionych na rzecz tej świątyni przez Sergiusza Kimbara, co mogło być związane z pożarem, który zapewne dość dotkliwie zniszczył jej wnętrze (Лちmonucb Супрасльскаго монастыря...., dz. cyt., s. 52-53). To również usprawiedliwiałoby potrzebę stworzenia nowego Deesis i innych ikon.

6 J. Jodkowski, dz. cyt., s. 266.

Szeroko na ten temat: A. Siemaszko, Malowidła ścienne cerkwi Zwiastowania w Supraślu. Rekonstrukcja programu ikonograficznego, „Zeszyty Naukowe Uniwersytetu Jagiellońskiego MCLXXIII. Prace z historii sztuki", 1995, z. 21, s. 41-42. być chęć zobaczenia ukończonej już dekoracji malarskiej świątyni oraz wyposażenia jej wnętrza ${ }^{8}$. Jednak najważniejszym argumentem przemawiającym za taką datacją wydaje się być sam zapis archimandryty, który w „Rejestrze” pisze: „Na początku rozpisano cerkiew świętą i ołtarz, a wydano na to 150 kop groszy litewskich (liczby?), oprócz jadła i podarków"9. Pamiętając, że dokument ten sporządzono w 1557 r., jako spis dokonań przełożonego klasztoru, jasnym wydaje się być, iż była to najprawdopodobniej jego pierwsza poważna inwestycja zrealizowana na początku urzędowania, a nie po 25 latach.

Program ikonograficzny malowideł, pokrywających ściany i sklepienia prezbiterium oraz wnętrza korpusu głównego cerkwi, oparty na wzorcach wypracowanych przez sztukę bizantyńską zawierał oryginalne rozwiązania autorskie zaczerpnięte z różnych źródeł. „Dominującą ideą supraskich malowideł było wcielenie Boga zobrazowane w różnorodny sposób, nawiązujące do wezwania świątyni [...]"10. Jak uważa A. Siemaszko: „Przegląd niektórych wątków tematycznych, a szczególnie bardzo rozbudowanego hagiograficznego wskazuje, że pochodzenie wielu przedstawień i pojedynczych postaci wyjaśnić można tylko znajomością bałkańskiej twórczości późno- i pobizantyńskiej, co [...] świadczy o pochodzeniu artystów działających w Supraślu"11. Teza ta koresponduje z zachowaną w źródłach informacją o działalności na terenie monasteru wspomnianego już Nektariusza. Jodkowski w swym artykule przytacza opinię M.W. Sołtanowa, który autorstwo supraskiej polichromii przypisuje atoskim lub południowo-słowiańskim mistrzom, dostrzegając w niej także ślady wpływów malarstwa włoskiego ${ }^{12}$. Niuanse te zauważył również S. Petković, twierdząc, iż przy pracach nad dekoracją cerkwi Zwiastowania brało udział co najmniej trzech mistrzów. Dostrzega w niej zarówno stylistykę właściwą: ,[...] dla centralnych obszarów ziem serbskich z lat sześćdziesiątych XVI w." "13, a wiec odpowiadającą Nektariuszowi, jak i tradycje odmienne dla sztuki bizantyńskiej, malarza o zupełnie innej orientacji ,[...] który przez zbieg okoliczności brał udział w zdobieniu świątyni prawosławnej” oraz jeszcze innego twórcy ,[...] który swoimi pojmowaniami był bliski malarstwu włoskiemu pierwszej połowy XVI w." 14

Jak się wydaje pierwsze uszkodzenie poprzez zasłonięcie supraskiej polichromii miało miejsce już XVII w. i wiązało się z zainstalowaniem w świątyni nowego ikonostasu $^{15}$, zajmującego całą ścianę wschodnią, sięgającego

\footnotetext{
8 A. Mironowicz, Dzieje monasteru supraskiego do połowy XVI wieku [w:] Rękopisy supraskie w zbiorach krajowych i obcych, opr. A. Mironowicz, Białystok 2014, s. 49.

9 Лвтопись Супрасльскаго монастыря...., dz. суt., s. 49.

10 A. Siemaszko, dz. cyt., s. 55.

11 Tamże, s. 55.

12 J. Jodkowski, dz. cyt., s. 266.

13 S. Petković, Nektarij Serb. Malarz z XVI wieku i jego działalność w klasztorze w Supraślu, „Rocznik Białostocki”, 1991, t. XVI, s. 311-312. 14 Tamże, s. 311-312.

15 P.P. Pokryszkin podaje, iż ikonostas ukończony został w 1664 r. w Gdańsku, a w jego budowie uczestniczył rzeźbiarz i złotnik Andrzej Modzelewski, zaś ikony do nowej przegrody malował niejaki „Wincenty". Natomiast z informacji zamieszczonych w opracowaniu J. Jodkow-
} 
swą szerokością do ściany północnej i południowej. W ten sposób naruszono strukturę malowideł ukazujących na ścianie południowej, zaczynając od górnego rzędu przedstawień: Narodzenie Chrystusa, ilustracje do 1 kontakionu Akatystu, medalion z popiersiem świętego oraz prawdopodobnie wizerunek św. Kosmy Pieśniarza (Hymnografa). Po stronie północnej uszczerbku doznały, w analogicznym układzie: Zstąpienie do otchłani, ilustracja do 10 oikosu Akatystu (?), medalion z popiersiem świętego, a także ujęcie Pawła Prostaka z czwartego rzędu wyobrażeń świętych. Konstrukcja ikonostasu zakryła również częściowo medaliony na gurtach łuków sklepiennych. Na północnym wizerunek św. Lukiana, na południowym św. Jana (il. 1). Podobnie było z przedstawieniem Zwiastowania na ścianie wschodniej, rozdzielonym na część południową z wizerunkiem Marii i północną z archaniołem Gabrielem ${ }^{16}$. Przypuszczać należy, iż pod tymi malowidłami znajdowały się jeszcze inne wypełniające dolną przestrzeń ścian rozdzielających nawę główną od prezbiterium.

Na początku lat pięćdziesiątych siedemnastego wieku miały powstać w świątyni także cztery ołtarze boczne, wystawione na cześć Zbawiciela - przy południowym filarze, Supraskiej Ikony Matki Bożej - przy północnym oraz Zwiastowania i św. Jana Teologa ${ }^{17}$. Fakt ten musiał spowodować zasłonięcie, a tym samym uszkodzenie malowideł pokrywających te partie filarów, gdzie przedstawieni byli święci męczennicy i rycerze. Były to zachodnia strona obu filarów oraz północna część filara południowego i południowa filara północnego (il. 2).

Kolejne straty przyniosło zamontowanie w cerkwi drewnianej boazerii, zakrywającej malowidła do wysokości okien (il. 3). Nie wiadomo czy było to spowodowane złym stanem polichromii, czy może bardziej świadomą zmianą wystroju świątyni? P.P. Pokryszkin odnotowuje

\footnotetext{
skiego wynikać może, że ikonostas został wykonany przed wystawieniem w świątyni czterech nowych ołtarzy bocznych, z Supraską Ikoną Matki Bożej w jednym z nich, która pierwotnie miała znajdować się w pierwszej przegrodzie ołtarzowej. Inwestycja ta miała mieć miejsce w latach 1642-1652 (J. Jodkowski, dz. cyt., s. 255). Analiza dostępnych źródeł, po części cytowanych m.in. przez prof. J. Maroszka (Ikonostas supraski 1643 r., „Białostocczyzna” 3/43/1996, s. 3), pozwala na postawienie tezy, iż montaż nowej konstrukcji ikonostasu rozpoczęto około 1642 r., lub nieco wcześniej. Przypuszczalnie do 1644 r. zakończono prace pozłotnicze najprawdopodobniej prowadzone przez wspomnianego wyżej snycerza - Andrzeja Modzelewskiego z Wilna oraz wypełniono pierwszy rząd przegrody nowymi wizerunkami. Natomiast zakończenie całej inwestycji, czyli wstawienie obrazów w dwóch kolejnych kondygnacjach, mogło trwać do 1664 r. (więcej na ten temat: K. Stawecka, Ikonostasy cerkwi Zwiastowania Bogarodzicy w Supraślu [w:] „Ikonosfera. Zeszyty muzealne", nr VI, 2017, w druku).

16 Identyfikacja malowideł za A. Siemaszko, dz. cyt., s. 39-49.

17 Tamże. Ikony Chrystusa i Bogarodzicy, wstawione do ołtarzach bocznych, mogły pochodzić ze starego ikonostasu, który w tym czasie został zastąpiony nową przegrodą ołtarzową. Jednak patrząc na zachowane zdjęcia z 1864 r. ukazujące te wizerunki, trudno się oprzeć wrażeniu, że mamy tu do czynienia $z$ obrazami pochodzącymi z tego samego okresu co nowe przedstawienia z ikonostasu wystawionego przez Nikodema Szybińskiego. Ich wygląd, odbiegający stylistycznie od szesnastowiecznych ikon, mógł być również wynikiem ,poprawek malarskich”, czego nie możemy wykluczyć. Natomiast ujęcia Zwiastowania i św. Jana Ewangelisty z Jozafatem Kuncewiczem były zapewne obrazami nowymi, wykonanymi specjalnie do ołtarzy bocznych.
}

pojawienie się „tabulatury” w czasach unickich, dodając, iż odkryte przez niego po usunięciu boazerii na północnej ścianie daty: 1751 i $1749^{18}$, pośród wydrapanych napisów, świadczą o tym, że panele położono tu nie wcześniej niż na to wskazują owe zapisy. Podobnie na jednym z malowideł, ze zbiorów Muzeum Ikon w Supraślu, pochodzącym z filaru świątyni odnajdujemy datę z pierwszej połowy XVIII w. - rok 1720 lub 1726 oraz nazwisko Srzedzinski, a nad nim przypuszczalnie widnieje imię Mateusz ${ }^{19}$ (il. 4). Biorąc powyższe pod uwagę, nasuwa się myśl, iż barokowo-rokokowe dekoracje i wyposażenie cerkwi powstałe w duchu zachodnioeuropejskiej sztuki, przybliżające jej wystrój do wnętrza kościelnego, zostały zamontowane w 2 . poł. XVIII w. ${ }^{20}$ Wskazuje na to również wzmianka, odnotowana przez Pokryszkina, mówiąca o ozdobieniu w 1770 r. (1771) prezbiterium znakomitą pod względem artystycznym sztukaterią i malowidłami, co oczywiście skutkowało zniszczeniem fresków, na których mieli być ukazani świeci hierarchowie i diakoni ${ }^{21}$ (il. 5). Z inwestycją tą można wiązać malarza Antoniego Gruszeckiego vel Dombrowskiego, który jako bazylianin apostata wrócił do zakonu w $1770 \mathrm{r}$. i osiadł w Supraślu. Rok później przełożony klasztoru miał podpisać umowę na odnowienie wnętrza cerkwi $\mathrm{z}$ bliżej nieznanym malarzem. Jak podaje E. Rastawiecki ${ }^{22}$ - największym dokonaniem Gruszeckiego było właśnie malowanie kościoła bazylianów w Supraślu „al fresko” w $1774 \mathrm{r}^{23}$ Jednocześnie stwierdzić należy, iż polichromie w dolnych partiach ścian i filarów w końcu XVII i w wieku XVIII musiały być już dość mocno zniszczone, o czym świadczą wspominane napisy znajdujące się pośród innych, gęsto wypełniających dolne partie ścian. Na fotografiach dokumentujących prace przy odsłanianiu malowideł w 1908(? $)^{24}$, gdzie utrwalono również zdjętą, stojącą obok

18 Pokryszkin dodaje przy tej dacie uwagę, że cyfra 4 podobna jest tu także do cyfry 9 (dz. cyt., s. 8).

19 Fragment postaci świętego męczennika, technika mieszana (fresk z wykończeniem temperowym), 70 × 83 cm, 1532-1557, Supraśl, $\mathrm{MI} / \mathrm{I} / 31$.

20 Działania te wpisują się w postępującą w owym czasie latynizację świątyń objętych unią, co szczególnie nasiliło się po synodzie zamojskim (1720).

$21 \quad$ P.P. Pokryszkin, dz. cyt., s. 8, 11. Zaznaczyć przy tym należy, iż $\mathrm{w}$ wielu opracowaniach, w odniesieniu do zmian, jakie zaszły w wystroju prezbiterium, pojawia się data $1771 \mathrm{r}$. Tak też Pokryszkin podpisuje w swym opracowaniu ilustrację ukazującą fragment części ołtarzowej (ryc. 17), nie zważając przy tym, iż w tekście dwukrotnie podał w tym kontekście $1770 \mathrm{r}$.

22 E. Rastawiecki, Stownik malarzów polskich, t. III, Warszawa 1857, s. 115 .

23 S. Stawicki, dz. cyt., s. 37-37.

24 A. Siemaszko podaje w odniesieniu do tych wydarzeń 1909 r. (por. dz. cyt., il. 33,34 ). Data ta pojawia się również przy innych fotografiach publikowanych w pracy P.P. Pokryszkina. Wiemy, iż autor został oddelegowany do zbadania supraskiej cerkwi Zwiastowania NMP, na podstawie pisma biskupa białostockiego Włodzimierza (Tichonickiego, 1873-1959) wystosowanego w 1907 r. do Cesarskiej Komisji Archeologicznej. Hierarcha prosił w nim o przeprowadzenie remontu i restauracji przebudowanej przez unitów świątyni (P.P. Pokryszkin, dz. cyt., s. 2). Wysoce prawdopodobnym jest, że pierwszy rekonesans - jaki przeprowadzał w Supraślu Pokryszkin - odbywał się jeszcze w tym samym roku (24-26 sierpnia 1907 r.), o czym pisze A. Musin w najnowszym opracowaniu odnoszącym się do zbiorów supraskich w archiwum naukowym Instytutu Historii Kultury Materialnej Rosyjskiej Akademii Nauk w Sankt Peters- 
„tabulaturę”, zauważamy wcześniejsze zabielenie fresków, o czym także pisze Pokryszkin (il. 6). Na skutek tych dzialań zniszczono czwarty rząd programu ikonograficznego świątyni z pełnofigurowymi przedstawieniami świętych, jakie pokrywały dolne partie ściany południowej i północnej. Były to w kolejności wizerunki świętych, od południa: Kosmy Pieśniarza, Jana z Damaszku, Józefa Hymnografa(?), Onufrego, Piotra z Athos, Izzaka z Syrii oraz od północy: Pawła Prostaka, Makarego Wielkiego, Pawła z Teb, Nifonta, Hilariona i Efrema ${ }^{25}$. Malowidła na południowej ścianie, naprzeciw kopuły, miały być restaurowane jeszcze w 1910 r. przez artystę F.F. Bodalewa, jednak bez wiedzy Cesarskiej Komisji Archeologicznej. Pokryszkin konstatował, iż zadowalająco poprawione zostały jedynie oblicza, zaś napisy, partie postaci oraz dolny fryz dekoracyjny z namalowaną tkaniną potraktowano pośpiesznie, niestarannie i mało wiernie, zalecając usuniecie tej niedbałej restauracji ${ }^{26}$ (il. 7). Odsłonięcie tych partii ścian, zarówno po stronie południowej, jak i północnej, ujawniło wykute symetrycznie nisze, powstałe jeszcze przed zainstalowaniem paneli. Ich uszkodzona konstrukcja uwidoczniła fragmenty szesnastowiecznego cokołu cerkwi (patrz il. 6).

Z opisanymi wyżej przekształceniami wnętrza cerkwi wiązać należy również umieszczenie chóru ciągnącego się przez całą zachodnią ścianę i opierającego się na ścianach północnej i południowej (il. 8). Pokryszkin w bezpośredniej relacji z oględzin tego miejsca podaje, że z powodu zainstalowania balkonu zbito więcej niż połowę znajdujących się tam malowideł, dodając, że rząd z medalionami i znajdujące się pod nim partie fresków zakryto tabulaturąa $^{27}$. W tej części świątyni zachowały się jedynie fragmenty cyklu akatystowego. Według ustaleń A. Siemaszki po lewej stronie arkady chóru ulokowane były ujęcia obrazujące: kontakion 5, oikos 5 i kontakion 6 Akatystu - czyli Podróż, Pokłon i Powrót Trzech Króli. Natomiast z przedstawień ulokowanych po prawej stronie znany jest jedynie obraz oikosu 6, który ilustrowano sceną ucieczki do Egiptu. Konstrukcja chóru naruszyła także ostatni obraz z cyklu akatystowego na ścianie południowej, wyobrażenie odnoszące się do kontakionu 4 oraz fragment pierwszego przedstawienia na ścianie północnej obrazującego oikos $8^{28}$. Degradację fresków na zachodniej ścianie dopełniała pojawiająca się tu pleśń widoczna w szparach tynku ${ }^{29}$.

burgu, gdzie przechowywana jest spuścizna po Cesarskiej Komisji Archeologicznej (Zabytki Supraśla w Sankt Petersburgu: materiały dotyczace historii i konserwacji cerkwi Zwiastowania Bogarodzicy (1907-1910) w archiwum Cesarskiej Komisji Archeologicznej [w:] Szesnastowieczne freski supraskie. Katalog zbiorów, red. nauk. K. Stawecka, red. A. Jurgilewicz-Stępień, K. Stawecka, w druku). Jak pisze badacz, Pokryszkin miał odwiedzić Supraśl trzy razy, w roku: 1907, 1908 i 1910. Podczas jego drugiej wizyty w 1908 r. (18-26 czerwca), powstała większość fotografii dokumentujących cerkiew, jej wnętrze i zabudowania monasterskie. Z ta datą związana jest również informacja na temat odsłonięcia malowideł po zdjecciu tabulatury.

25 Identyfikacja malowideł za A. Siemaszko, dz. cyt., s. 46-47.

26 P.P. Pokryszkin, dz. cyt., s. 12. J. Jodkowski w swoim artykule również przytacza te informacje (dz. cyt., s. 264)

27 Tamże, s. 16.

28 A. Siemaszko, dz. cyt., s. 44.

9 P.P. Pokryszkin, dz. cyt., s. 16
Spustoszenie w supraskiej polichromii przyniosło także pobielenie pewnych jej fragmentów. Jak podaja przedwojenni badacze, zakrycie malowideł pobiałą było konsekwencją fatalnego stanu dachu. Na początku XIX w. mówiło się nawet o jego skrajnym zbutwieniu, zaś w połowie tego stulecia wspomina się o wodzie stojącej na strychu. W kontekście bielenia ścian cerkwi wymieniane są lata $1828,1852-1859$ i $1876^{30}$. W przekazach pojawia się nazwisko ihumena Wincentego Kurhanowicza, który miał zlecieć wykonanie tych prac ${ }^{31}$, za co otrzymał karę cerkiewną ${ }^{32}$. Niebielone miały być jedynie sklepienie nad soleą, powierzchnie na wszystkich łukach i malowidło w kopule - wizerunek Chrystusa ${ }^{33}$. Dzięki darowiźnie pobiała została usunięta suchym sposobem w 1887 r. Jednak uszkodzone w trakcie tych czynności miejsca poprawiono jedynie powierzchownie ${ }^{34}$.

Pierwsze prace „restauratorskie”, które musiały trwać od końca XIX w., zamiast poprawić kondycję supraskiej polichromii przyniosły wiele strat $\mathrm{w}$ oryginalnej warstwie malarskiej. Stan fresków na początku XX w., a także wtórne, nieudolne ingerencje malarskie szczegółowo opisuje w swej pracy P.P. Pokryszkin. Dokumentację strat rozpoczyna od malowidła znajdującego się w kopule, odnotowując bardzo niezręczne i niewierne przemalowania $\mathrm{w}$ jaskrawych barwach z dodatkiem ciemnego brązu. Badacz zaznacza przy tym, iż freski $\mathrm{w}$ tamburze prawdopodobnie przetrwały w stanie pierwotnym. Dalsze poprawki malarskie zauważone zostają na gurcie północnego filara, gdzie popsuto wizerunki dwóch świętych. Na ścianie północnej niedbale poprawiono niemal wszystkie sceny świąteczne: Zesłanie Ducha Świętego, Przemienienie Pańskie i Zstąpienie do otchłani, a ponadto, jak to określa naoczny świadek, „popsuto” cały rząd z medalionami, w których wyobrażono świętych. Wśród malowideł wschodniej ściany wymienione zostaje bardzo zniszczone i przemalowane przedstawienie Archanioła Gabriela. Podobnie jak w północnej części programu ikonograficznego, tak i w południowej nieudolne ingerencje malarskie zniekształciły trzy ujęcia świąt: Narodzenia Chrystusa, Chrzest Pański oraz Spotkanie Pańskie. Także na południowej ścianie odnotowane zostało przemalowanie rzędu ilustrującego Akatyst, zwłaszcza w partiach przy ikonostasie, gdzie również

\footnotetext{
30 Tamże, s. 12; J. Jodkowski, dz. cyt., s. 264-265.

s. Stawicki powołując się na inwentarz klasztoru z 1882 r., podaje, że większa część malowideł pokryta została pobiałą wapienną ok. 1850 r. Wzmiankuje jeszcze o badaniach fresków, które miały mieć miejsce w 1866 r. oraz o odsłonięciu polichromii i wykonaniu prac restauratorskich w latach 1886-1889 (dz. cyt., s. 35).

31 L. Lebiedzińska, dz. cyt., s. 24.

P.P. Pokryszkin, dz. cyt., s. 12.

33 Przedstawienie Chrystusa w kopule choć nie było pobielone, jak podają pierwsi badacze supraskiej świątyni, to nie uniknęło późniejszych „restauracji”. Fakt ten wyraźnie dokumentują fotografie wykonane w 1864 (Pietrow) oraz w 1909 (1910?). Na drugim ujęciu widzimy rozbudowaną kompozycję malowidła o dodatkowe wizerunki serafinów, których wcześnie najprawdopodobniej nie było oraz elementy dekoracji roślinnych umieszczonych wokół okien. W „restauracji” tej poraża nieudolność malarska wykonawcy.

34 Tamże, s. 12. Podobnie tą kwestię opisuje J. Jodkowski (dz. cyt., s. 264).
} 
znajdowały się całkowicie zniszczone dwa medaliony oraz trzeci mniej uszkodzony. W tym czasie nie było już przy nich napisów. Podobny brak podpisów wzmiankowany jest przy obrazach świętych umieszczonych na filarach. Na północnym zachowane napisy były nieczytelne, zaś poprawiane wizerunki mocno porysowane. Na południowym wszystkie przedstawienia, oprócz św. Jerzego, nie miały już napisów bądź też, podobnie jak na filarze północnym, zasłonięte były kiotami i innymi elementami wyposażenia wnętrza. W odsłoniętych partiach malowideł dwa wyobrażenia były bardzo nieumiejętnie przemalowane, pozostałe porysowane. Zauważono także $\mathrm{w}$ odniesieniu do wszystkich supraskich malowideł poczerniałe aureole. Autor tej analizy zniszczeń kończąc swój opis, podkreśla, że nieumiejętne poprawki malarskie od razu rzucają się w oczy i wywołują oburzenie ${ }^{35}$. Konkludując swoją wypowiedź, stwierdza, iż należy podjąć starania, aby freski doprowadzić do należytego stanu, dodając przy tym uwagę na temat niedawno namalowanych ornamentów na wąskich krzyżowych sklepieniach, które ocenia jako poprawne, sugerując jednak ich dokładną analizę $e^{36}$. W dużo ostrzejszych słowach o polichromii supraskiej wypowiada się w 1915 r. J. Jodkowski, pisząc, iż jest ona „w opłakanym stanie”, nazywając przeprowadzoną ,restaurację” barbarzyńską i wyrażając swoje oburzenie, iż pomimo krytycznej opinii wydanej przez Pokryszkina w 1911 r. (data publikacji opracowania), to już w $1913 \mathrm{w}$ cerkwi ponownie pracował F.F. Bodalew, który niedbale przemalował odkryte na ścianie północnej freski. Jodkowski zaleca przy tym, aby tę część malowideł, która nie podzieliła losów większości z nich, objąć osobnymi badaniami ${ }^{37}$.

W 1930 r. nad freskami supraskimi pracował Jan Zachwatowicz (wówczas pracownik Wydziału Architektury Politechniki Warszawskiej, asystent w Katedrze Rysunku Odręcznego). Według Zachwatowicza zabielone wcześniej freski zostały niedokładnie umyte. Przeprowadzone przez niego próby konserwacji dawały zadawalające efekty. Tak opisywał swoja pracę: „Próbowałem odmywać fragmentami i skutek jest zupełnie dobry, barwy są żywe i nie są przerywane szarymi plamami, koniecznie będę dążył żeby wymyć spod nowych farb „Narodzenie”, bo farby te klejowe, dają się usunąć, a fresk od mycia nie ucierpi" ${ }^{38}$. Jak wynika z zapisków Zachwatowicza, oprócz oczyszczania malowideł podjął się on również ich retuszowania, nie wiemy jednak w jakim zakresie prace te były prowadzone ${ }^{39}$.

\footnotetext{
35 S. Stawicki na podstawie badań laboratoryjnych ocenił kwestie technologiczne przeprowadzonych wówczas „restauracji”. Przede wszystkim wyodrębnił w badanych próbkach fresków pigmenty niezalecane bądź zupełnie nienadające się do malowideł ściennych. Były to: biel ołowiowa, biel cynkowa, biel barytowa, żółcień chromowa, żółcień cynkowa, indygo, bliżej nieokreślona czerwień organiczna, błękit pruski, ultramaryna syntetyczna (dz. cyt., s. 36).

36 P.P. Pokryszkin, dz. cyt. s. 17.

37 J. Jodkowski, dz. cyt., s. 266.

38 K. Zachwatowicz-Jasieńska, Dokumentacja i konserwacja wyposażenia światyni. Zachwatowiczowie w Supraślu [w:] Supraśl 1913. Dokumentacja fotograficzna Józefa Jodkowskiego cerkwi Zwiastowania Najświętszej Marii Pannie, Warszawa 2016, s. 228-229, 232.

39 Tamże, s. 219-222.
}

Niemal totalna dewastacja dekoracji malarskiej świątyni nastąpiła podczas II wojny światowej. Najpierw w okresie 1939-1941 okupanci radzieccy dokonują wielu aktów wandalizmu, wykłuwając tynki na obliczach świętych, strzelając do przedstawień, a nawet do wizerunku Chrystusa w kopule. Sowieci urządzają we wnętrzu cerkiewnym warsztat, niszcząc tym samym malowidła mechanicznie. Dolne partie ulegają okopceniu. Kres istnienia fresków supraskich przyniosły wydarzenia z końca lipca 1944 r., kiedy to wycofujące się z Supraśla wojska hitlerowskie wysadziły $\mathrm{w}$ powietrze cerkiew Zwiastowania NMP (il. 9).

W dokumentacji wykonanej w 1946 r. przez Marię Brykowską zawarty jest opis miejsca, w którym mowa jest o całkowitym zburzeniu ścian świątyni. Z całej konstrukcji przetrwały tylko dwa ośmioboczne filary oraz fragmenty wewnętrznych ścian nawy głównej, a także część przybudówki znajdującej się przy południowo-wschodnim narożniku cerkwi. Partie malowideł wraz z tynkiem ocalały jedynie na filarach (il. 10). Wspomniana inwentaryzacja poprzedziła transfer zachowanych fresków, który prowadzono do 1947 r. Pracami kierował Władysław Paszkowski, pełniący wówczas funkcję wojewódzkiego konserwatora zabytków, który działał z polecenia Konserwatora Generalnego Ministerstwa Kultury i Sztuki prof. Jana Zachwatowicza ${ }^{40}$. Dzięki temu zabezpieczono 33 metry kwadratowe polichromii, w obrębie których znalazło się 30 większych fragmentów i wiele mniejszych ${ }^{41}$. Pierwotnie stanowiły one dekorację filarów cerkwi i przedstawiały świętych męczenników i rycerzy oraz tworzyły pasy ornamentalne na pionowych płaszczyznach i zwieńczeniach filarów. Niektóre z fresków ocalały w dość dobrym stanie, inne były całkowicie rozbite. W całym tym zbiorze wyodrębniono siedem pełnych postaci i trzy medaliony ${ }^{42}$. Przebieg i zakres prac, które przeprowadzał konserwator F. Konecki, ilustruje po części opis zawarty w dokumentacji konserwatorskiej z roku 1965: „Ocalałe fragmenty tynku wraz z malowidłem zdjęto ze ścian i słupów przez odcięcie od cegły. Podzieliwszy na obrazy wg kompozycji w ten sposób, że każdy obraz przedstawia jedną postać i jest obrazowy, czyli przedstawia pewną całość kompozycyjną. Pozostawiony tynk na grubości od $3 \mathrm{~mm}$ do $4 \mathrm{~cm}$ i został zalany od tyłu gipsem. Gips wzmocniono drutem. Druty w chwili przejęcia obiektu przez PKZ były przeżarte rdzą. Niektóre z murków były wzmocnione tylko pasami dartymi z płótna. Każdy z murków był w drewnianej ramie $\mathrm{z}$ listew nieheblowanych" ${ }^{43}$. Tak zabezpieczone transfery fresków przechowywane były do początków lat sześćdzie-

\footnotetext{
40 Z 7 listopada 1945 r. pochodzi pismo, w którym Zachwatowicz odnosi się do wcześniej nadesłanego z Białegostoku kosztorysu dotyczącego budowy zadaszenia nad ruinami cerkwi. Zaleca w nim, aby zdjąć i zabezpieczyć pozostałe fragmenty polichromii (K. Zachwatowicz-Jasieńska, dz. cyt., s. 232).

41 Tamże, s. 13-14

42 L. Lebiedzińska, dz. cyt., s. 22.

43 K. Stawicka, Dokumentacja konserwatorska PKZ, Warszawa 1965, mps., s. 12, cyt. za: Konserwacja XVI-wiecznych pobizantyjskich fresków z Supraśla. Dokumentacja konserwatorska, Monument Service Marcin Kozarzewski, Michałowice 2012, s. 16.
} 
siątych w magazynach Urzędu Wojewódzkiego w Białymstoku, przy ul. Mickiewicza $5^{44}$.

Od marca 1964 r. do grudnia 1965 (maja 1966) (5) $^{45}$ ocalałe fragmenty fresków poddano zabiegom konserwatorskim w Przedsiębiorstwie Państwowym Pracownie Konserwacji Zabytków w Warszawie. Prace prowadzone były pod kierunkiem Kaliny Stawickiej (starszego konserwatora) z udziałem Eleny Berłowicz, Alicji Ziółkowskiej, Stanisława Stawickiego i Barbary Pawłowskiej. Całość czynności nadzorował główny konserwator i kierownik Pracowni Konserwacji Malarstwa - Maria Orthwein. Badania laboratoryjne wykonał Piotr Rudniewski ${ }^{46}$. Konsultantem zespołu był prof. Bohdan Marconi ${ }^{47}$ (il. 11).

Pierwsze zabiegi konserwatorskie polegały na utrwaleniu warstwy malarskiej za pomoca polioctanu winylu oraz zabezpieczeniu lica poprzez kolejne naklejenie papieru o różnej gramaturze $\mathrm{z}$ użyciem spoiwa $\mathrm{w}$ postaci metylocelulozy, alkoholu poliwinylowego, kleju glutynowego i klajstru. Dla fresków zachowanych w łukowatym kształcie oraz posiadających znaczne nierówności powierzchni wykonano gipsowe negatywy lica. Tak przygotowane obiekty odwracano licem do dołu i kontynuowano konserwacje kolejnych murków od strony odwrocia. W tej części prac najpierw zeszlifowano tynki do grubości 1,5 $\mathrm{cm}$. Następnie nałożono zaprawę wyrównującą wapienno -piaskową i umieszczono malowidła w ramie drewnianej z siatką ocynkowaną, osadzając je na klej epoksydowy. Następnie odwrocia zalano gipsem z dodatkiem wapna, do którego dodano $1 \%$ polialkohol winylu. Po wykonaniu powyższych zabiegów malowidła odwrócono i usunięto zabezpieczenie lica. $\mathrm{W}$ dalszej kolejności wypełniono ubytki podłoża prawdopodobnie kitem adekwatnym do $\mathrm{muru}^{48}$. Po opracowaniu kitów przystapiono do ich retuszy za pomocą pionowej kreski (tratteggio) ${ }^{49}$. Przetarcia warstwy malarskiej na zaprawie oryginalnej lub podmalówce pozostawiono bez punktowań. Niestety nie wiemy jakie farby wówczas zastosowano. Jeszcze w trakcie prowadzonych prac konserwatorskich, w styczniu 1965 r., 18 tablic z malowidłami zostało wystawionych w Muzeum Narodowym w Warszawie na wystawie „Ochrona dóbr kultury województwa białostockiego w XX-leciu PRL”. Po zakończeniu ekspozycji freski wróciły do pracowni, gdzie poddawane były kolejnym zabiegom. Dopiero w maju 1966 r. zachowane malowidła powróciły do Białegostoku. Tu

\footnotetext{
44 S. Stawicki, dz. cyt., s. 8.

45 L. Lebiedzińska, dz. cyt., s. 20

46 Piotr Rudniewski wyniki swych badań opublikował w pracy: Technika malowidel bizantyńsko-ruskich na przykładzie polichromii ściennych w Lublinie i Supraślu, „Biblioteka Muzealnictwa i Ochrony Zabytków. Seria B", t. XI (1965), s. 96-102.

47 L. Lebiedzińska, dz. cyt.

48 Nie posiadamy informacji na temat składu zastosowanego kitu. Mogły to być kity wapienno-piaskowe. L. Lebiedzińska podaje, iż były to kity wykonane $\mathrm{z}$ wapna $\mathrm{i}$ oryginalnej zaprawy zdjętej $\mathrm{z}$ odwrocia (dz. cyt., s. 22).

49 Tratteggio - technika barwionego retuszowania stosowana głównie przy renowacji malarstwa ściennego. Polega na uzupełnieniu braków $\mathrm{w}$ warstwie malarskiej za pomoca nanoszenia w tych miejscach drobnych, równoległych, pionowych linii (kresek). Widziane z daleka są odbierane przez oko ludzkie jako część malowidła.
}

w 1968 r., z inicjatywy Wojewódzkiego Konserwatora Zabytków, a także Muzeum Okręgowego w Białymstoku $\mathrm{w}$ salach ratusza zorganizowano prezentację wszystkich odrestaurowanych fresków. Po dziesięciu latach wystawę przeniesiono do Supraśla, lokując ją w dawnej kaplicy Pałacu Opatów ${ }^{50}$. Na przełomie 1979 i 1980 r. tablica z przedstawieniem św. Oresta (MI/I/19) weszła w skład ekspozycji konserwatorskiej organizowanej we Frankfurcie przez warszawski oddział PKZ. Zmiany w lokalizacji tablic z pozostałością supraskiej polichromii nastąpiły wraz z utworzeniem w 2006 r. Muzeum Ikon w Supraślu. W tym czasie cały zespół malowideł został włączony do kolekcji nowo powstałej placówki, stając się jej najważniejszą częścią.

Eksponowanie fresków w różnych warunkach wystawienniczych przez okres około pięćdziesięciu lat spowodowało konieczność przeprowadzenia ponownych działań konserwatorskich zachowujących w należytym stanie ten bezcenny zabytek. Realizacja tych założeń była możliwa dzięki pozyskaniu dofinansowania na ten cel z Ministerstwa Kultury i Dziedzictwa Narodowego, które dwukrotnie wspomogło finansowo konserwacje fresków. Pierwszy etap prac, przeprowadzonych przez zespół pracowni Monument Service pod kierunkiem Pana Marcina Kozarzewskiego, obejmujący 22 fragmenty malowideł, rozpoczęto w 2012 r., drugi zrealizowano w 2014 r. (8 tablic). Przebieg czynności i zastosowane środki w obu przypadkach były takie same. Rozpoczęły je szczegółowe oględziny i badania, które wykazały dobry stan zastępczego podłoża nośnego, co pozwoliło na ukierunkowanie konserwacji na przywrócenie freskom pierwotnych wartości artystyczno-estetycznych i zabezpieczenie ich przed dalszą degradacją. Podstawowym problemem były uszkodzenia malowideł na styku murowanego podłoża i drewnianej ramy (powstawały w tych partiach naprężenia wynikające z pracy drewna). Drugim zagadnieniem konserwatorskim były zmiany kolorystyczne zarówno oryginalnej warstwy malarskiej, jak i w wykonanych w latach sześćdziesiątych retuszach $^{\text {51 }}$ (il. 12).

Aby zapobiec powstawaniu uszkodzeń przy drewnianych ramach, wykonano dylatację wzdłuż ich wewnętrznych krawędzi, którą uzupełniono silikonem i wypełniono zaprawą wapienną z dodatkiem szpachli akrylowej. W dalszej kolejności podklejono odspojenia Primalem AC 33 w stosunku 1:3 z wodą (część „łusek” położono za pomocą kautera, wykorzystując wprowadzony w trakcie poprzedniej konserwacji polioctan winylu) oraz wzmocniono warstwę malarską 3-4\% kazeiną amonową z dodatkiem $10 \%$ etanolu. Następnie oczyszczono lica pastą z kwaśnego węglanu amonu (NH4HCO3) w stężeniu 8\% w $3 \%$ celulozie, uzupełniono braki warstwy zaprawy

\footnotetext{
50 Wystawa w salach białostockiego ratusza trwała od marca 1968 do maja 1978 r. Przeniesienie ekspozycji do Supraśla wiązało się z utworzeniem tu punktu muzealnego Muzeum Okręgowego w Białymstoku.

${ }^{51}$ Konserwacja XVI-wiecznych pobizantyjskich fresków z Supraśla. Dokumentacja konserwatorska, Monument Service Marcin Kozarzewski, Michałowice 2012, s. 50. Przed przystąpieniem do prac wykonano wstępną dokumentację fotograficzną i opisową, przeprowadzono badania w świetle wzbudzonym promieniowaniem UV oraz utworzono mapy stanu zachowania poszczególnych warstw stratygraficznych. Tamże, s. 66.
} 
kitami, na których wykonano retusze farbami akwarelowymi. Duże powierzchnie kitów scalono kolorystycznie (kolor zaprawy). Fragmenty malowideł osadzone niewłaściwie wyjęto z ram i zamontowano ponownie na zaprawie piaskowo-wapiennej stosując Primal AC33. W trakcie tych prac usunięto także czarną farbę $\mathrm{z}$ drewnianych ram. Otwory i pęknięcia w drewnie wypełniono kitem żywicznym z trocinami o małej granulacji, po czym ramy pomalowano farbą akrylową na biało. Oprócz poprawy stanu zachowania fresków przeprowadzona konserwacja ujawniła ślady po napisach odkryte na trzech tablicach. Przy postaci świętego męczennika, na fragmencie malowidła oznaczonego numerem inwentarzowym $\mathrm{MI} / \mathrm{I} / 31$, nad prawym ramieniem postaci widoczne są litery: FILI - kolejna litera jest nieczytelna (patrz il. 4). Na dwóch pozostałych przedstawieniach widoczne są pojedyncze litery (MI/I/29, MI/I/33). Odkryte inskrypcje wymagają głębszych analiz, które przynieść mogą identyfikację zobrazowanych postaci.

Podsumowując temat historii zniszczeń oraz konserwacji i restauracji, jakie zostały w przeciągu wieków przeprowadzone nad freskami supraskimi, warto przytoczyć słowa ostatnich wykonawców tych prac, traktując je jako warunek, który powinien przyświecać nam w dalszej opiece nad tym unikatowym zabytkiem: „Założeniem nadrzędnym jest poszanowanie autentyku i historii [...] fresków supraskich. Celem prac konserwatorskich i restauratorskich przy transferach [...] [pozostaje - K.S.] utrwalenie zabytkowej materii wszystkich warstw technologicznych, [oraz - K.S.] zabezpieczenie ich przed dalszą degradacją $[\ldots]^{\prime \prime}{ }^{52}$.

52 Konserwacja XVI-wiecznych pobizantyjskich..., dz. cyt., s. 61.

\section{Ilustracje}

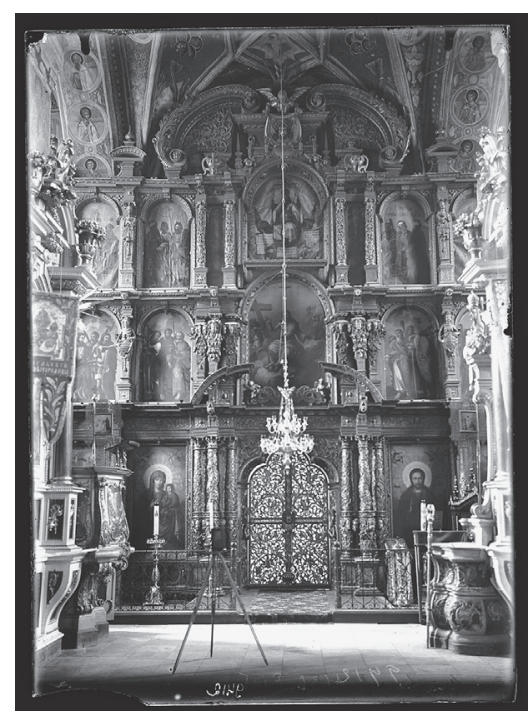

1. Ikonostas w cerkwi Zwiastowania NMP w Supraślu, 1. poł. XVII w., fotografia $\mathrm{z}$ pocz. XX w., zbiory IS PAN w Warszawie, nr neg. 9412

2. Tron biskupi oraz dawny ołtarz
boczny poświęcony Zwiastowaniu Bogarodzicy, poł. XVII-XVIII w., filar południowy, cerkiew Zwiastowania NMP w Supraślu, fotografia z pocz. XX w., zbiory IS PAN w Warszawie, nr neg. 9413

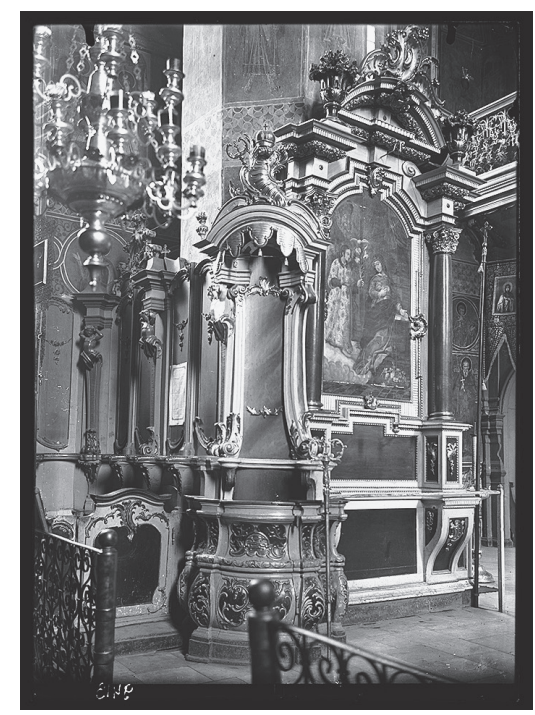

3. Tabulatura na ścianie południowej, XVIII w., cerkiew Zwiastowania NMP w Supraślu, fotografia z pocz. XX w., zbiory IS PAN w Warszawie, nr neg. 9411a

4. Fragment postaci świętego męczennika, technika mieszana (fresk z wykończeniem temperowym), 70 x 83 cm, 1532-1557, Supraśl, Muzeum Ikon w Supraślu Oddział Muzeum Podlaskiego w Białymstoku, $\mathrm{MI} / \mathrm{I} / 31$, fot. Cesar Delgado Martin - Monument Service

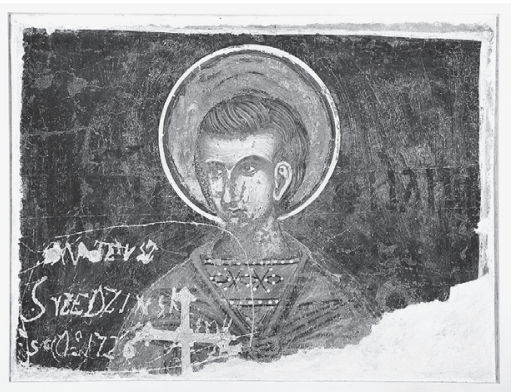



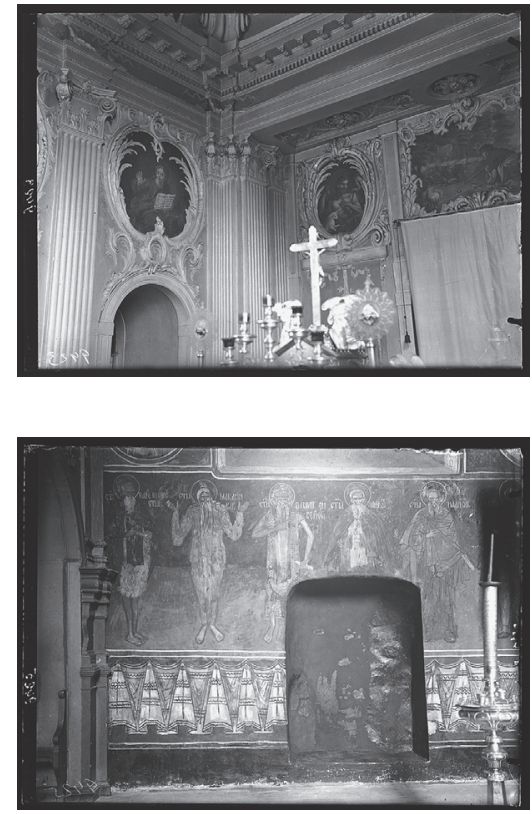

5. Część ołtarzowa (prezbiterium), 1770 (1771), cerkiew Zwiastowania NMP w Supraślu, fotografia $z$ pocz. XX w., zbiory IS PAN w Warszawie, nr neg. 9423

7. Ściana północna stan po przeprowadzonych „restauracjach”, cerkiew Zwiastowania NMP w Supraślu, fotografia sprzed 1915, zbiory IS PAN w Warszawie, nr neg. 9425

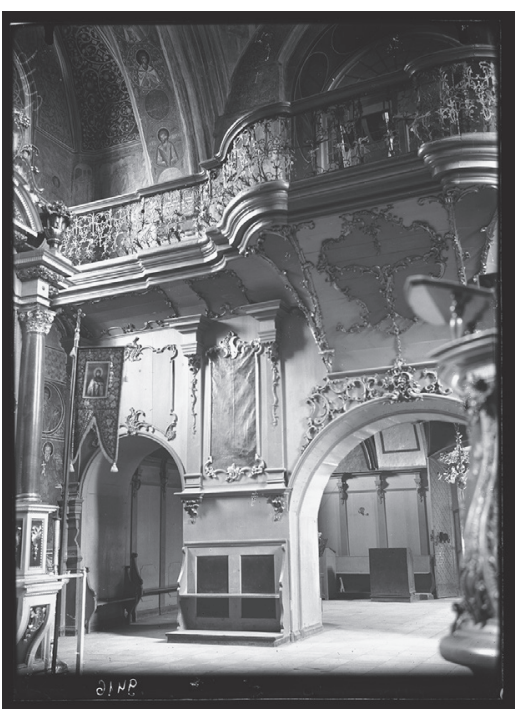

8. Chór, tabulatura na ścianie zachodniej, XVIII w., cerkiew Zwiastowania NMP w Supraślu, fotografia $\mathrm{z}$ pocz. XX w., zbiory IS PAN w Warszawie, nr neg. 9416

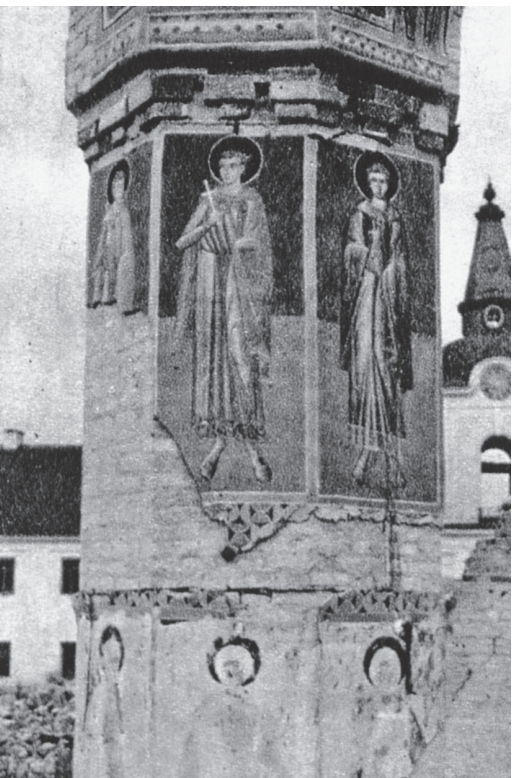

12. Dokumentacja konserwatorska - wybrane fotografie, 2012 ,

Monument Service -

Marcin Kozarzewski, fot. Cesar Delgado Martin ar południowy, stan z 1945 L. Lebiedzińska, Freski z Supraśla. Katalog wystawy. Białystok 1968 Kraków 1968, il. 80

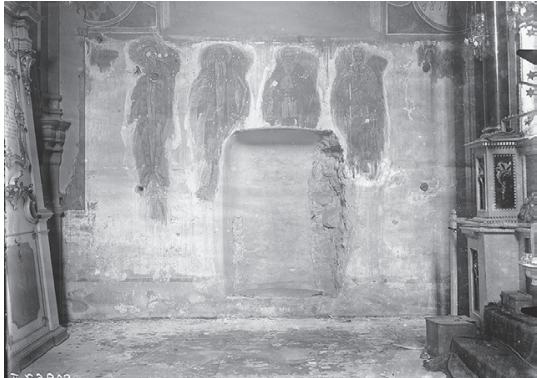

6. Ściana północna po zdjęciu tabulatury z częściowo odsłoniętymi malowidłami, cerkiew Zwiastowania NMP w Supraślu, stan z 1908(?), zbiory Archiwum

Naukowego Instytutu Historii Kultury Materialnej Rosyjskiej Akademii Nauk w Sankt Petersburgu, ФНА ИИМК РАН 8876

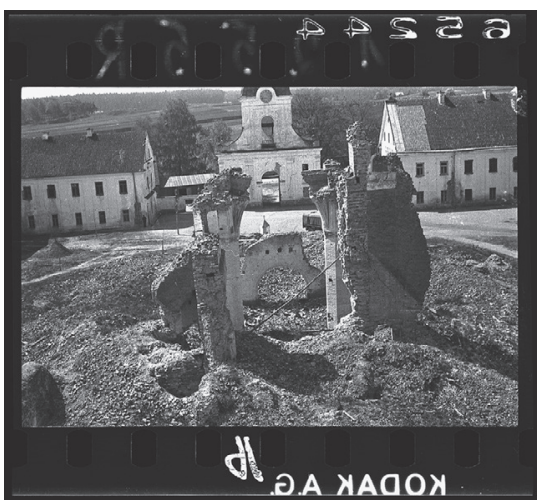

9. Ruiny cerkiew Zwiastowania NMP w Supraślu, 1947, fot. P. Koziński, zbiory IS PAN w Warszawie, nr neg. 1947

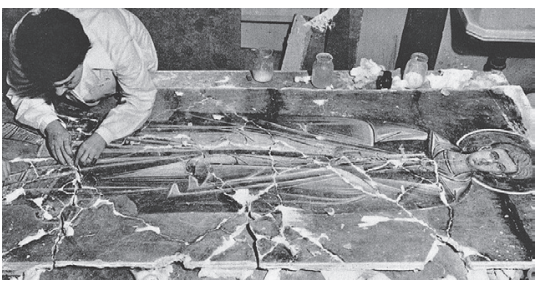

11. Prace konserwatorskie, 1964 , fragment fotografii, rep. za.:

L. Lebiedzińska, Freski z Supraśla. Katalog wystawy. Biatystok 1968, Kraków 1968, il. 70
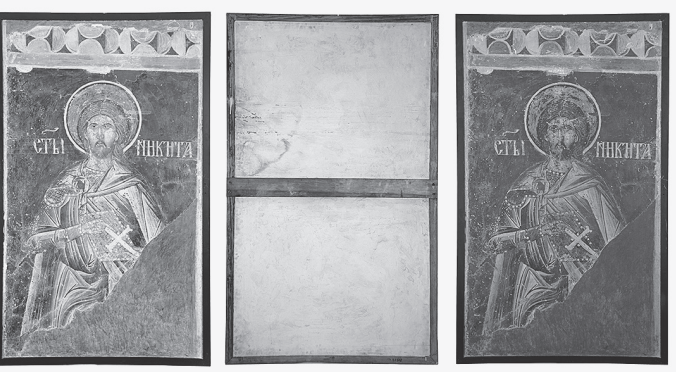


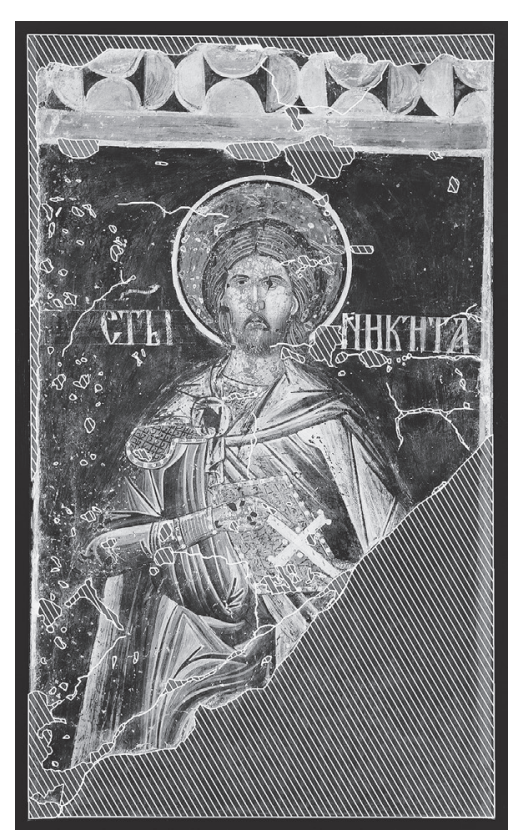

12.a. Mapa stanu zachowania malowidła, Monument Service Marcin Kozarzewski

12.c. Lico fresku w trakcie prac konserwatorskich i po ich zakończeniu, Monument Service - Marcin Kozarzewski

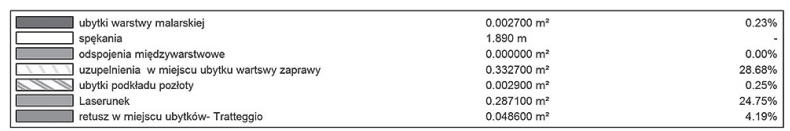

12.b. Opis do mapy stanu zachowania malowidła, Monument Service - Marcin Kozarzewski
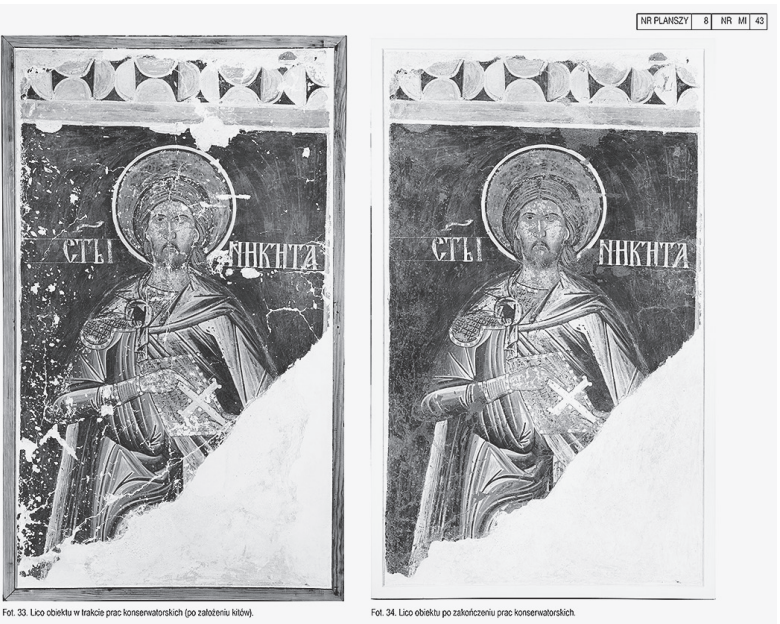

\section{Bibliografia}

Далматовъ Н., „Супрасльский Благовещенский монастырь. Историко-статистическое описание”, Санкт-Петербург 1892.

Иодковский И., Церкви приспособленныя къ обороне въ Литве и Литовской Руси [w:] Древности. Труды комиссии по сохранению древнихъ памятниковъ, остоящей при Императорскомь Московскомъ Археологическомь Обществе, т. VI, Москва 1915.

Konserwacja XVI-wiecznych pobizantyjskich fresków z Supraśla. Dokumentacja konserwatorska, Monument Service Marcin Kozarzewski, Michałowice 2012.

Lebiedzińska L., Freski z Supraśla. Katalog wystawy. Białystok 1968, Kraków 1968.

Летопись Супрасльской Лавры [w:] „Архэографический сборникъ документовъ относящихся къ истории северо-западной Руси”, т. IX, Вильна 1870.

Maroszek J., Ikonostas supraski 1643 r., „Białostocczyzna” 3/43/1996.

Musin A., Zabytki Supraśla w Sankt Petersburgu: materiały dotyczace historii i konserwacji cerkwi Zwiastowania Bogarodzicy (1907-1910) w archiwum Cesarskiej Komisji Archeologicznej [w:] Szesnastowieczne freski supraskie. Katalog zbiorów, red. nauk. K. Stawecka, red. A. Jurgilewicz-Stępień, K. Stawecka, w druku.

Petković S., Nektarij Serb. Malarz z XVI wieku i jego działalność w klasztorze w Supraślu, „Rocznik Białostocki”, 1991, t. XVI.
Покрышкинъ П.П., Благовэщенская церков въ Супрасльскомъ Монастырэ, Санкт-Петербург 1911.

Rastawiecki E., Słownik malarzów polskich, t. III, Warszawa 1857.

Rudniewski P., Technika malowideł bizantyńsko-ruskich na przykładzie polichromii ściennych w Lublinie i Supraślu, „Biblioteka Muzealnictwa i Ochrony Zabytków. Seria B”, t. XI (1965).

Siemaszko A., Malowidła ścienne cerkwi Zwiastowania w Supraślu. Rekonstrukcja programu ikonograficznego, ,Zeszyty Naukowe Uniwersytetu Jagiellońskiego MCLXXIII. Prace z historii sztuki", 1995, z. 21.

K. Stawecka, Ikonostasy cerkwi Zwiastowania Bogarodzicy w Supraślu [w:] „Ikonosfera. Zeszyty muzealne”, nr VI, 2017, w druku.

Stawicka K., Dokumentacja konserwatorska PKZ, Warszawa 1965, mps.

Stawicki S., Malowidla ścienne z dawnej cerkwi Zwiastowania NMP w Supraślu - problemy techniczne i technologiczne, „Biuletyn Konserwatorski Województwa Podlaskiego", 2004, z. 10.

Zachwatowicz-Jasieńska K., Dokumentacja i konserwacja wyposażenia światyni. Zachwatowiczowie w Supraślu [w:] Supraśl 1913. Dokumentacja fotograficzna Józefa Jodkowskiego cerkwi Zwiastowania Najświętszej Marii Pannie, Warszawa 2016. 
ISSN 1508-7719

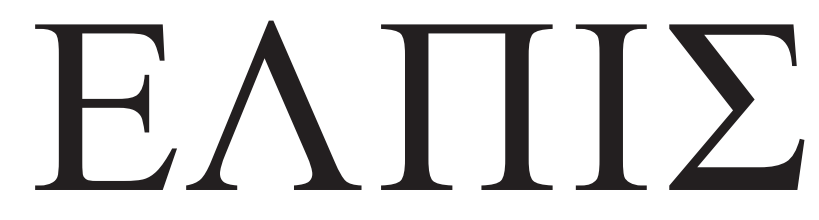

CZASOPISMO TEOLOGICZNE KATEDRY TEOLOGII PRAWOSŁAWNEJ UNIWERSYTETU W BIAŁYMSTOKU

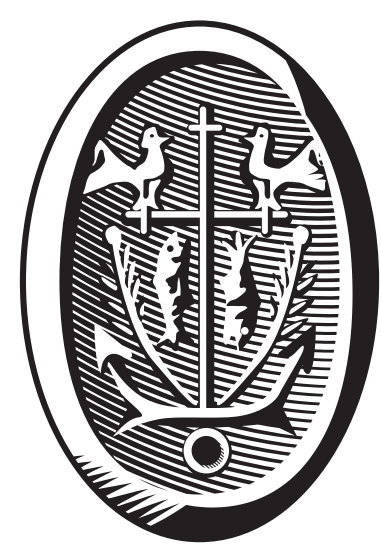

ADRES REDAKCJI

15-097 Białystok, ul. M. Skłodowskiej-Curie 14 tel. 85 745-77-80, e-mail: redakcja@elpis.edu.pl www.elpis.uwb.edu.pl 